\title{
Where Is the Risk? Is Agricultural Banking Really More Difficult than Other Sectors?
}

\author{
Klaus Maurer ${ }^{1}$
}

\section{Introduction ${ }^{2}$}

Banks and other financial institutions have been extremely reluctant to engage in rural finance - and even more so in agricultural finance - for a number of reasons. The remoteness of rural clients coupled with poor rural infrastructure and lack of branch networks imply a high cost of service delivery and, as a result, profitability is assumed to be low. The other main reason why commercial banks refrain from venturing into rural areas is the "high risk" associated with agricultural lending.

Is the "high risk" real and substantiated, or is it only perceived by banks? Is agricultural finance really more risky than finance in other sectors? Are the risks in agricultural finance too prohibitively high to be managed? These are some of the main questions of this chapter.

The topic is risk and risk management in agricultural finance. In a first step, the chapter defines, classifies, and analyzes the different types of risks in agricultural finance. A key message is that the specific risks of agricultural finance need to be seen and put into perspective with other risks. Based on this distinction, different approaches to risk management are developed. A segmentation of risks into layers serves as a basis for structured risk management solutions that involve the farmers themselves, the markets, and the government. Implications and perspectives are outlined in the final section, including the role of government and donors.

Agriculture and agricultural finance encompasses the whole range of producers and target groups from small, family farm households to specialized, SME-type commercial farmers to large agricultural enterprises and agribusinesses. However, access to finance has been most severely limited for small farmers and - to a cer-

\footnotetext{
Chairman of the Supervisory Board, Finance in Motion.

2 The preparation of the paper was financially supported by the German Federal Ministry for Economic Cooperation and Development (BMZ) via KfW development bank. The author acknowledges with appreciation the support and suggestions provided by Michael Jainzik, Piero Violante, other KfW staff and authors of other papers presented in this publication.
} 
tain extent - for emerging commercial farmers. ${ }^{3}$ Therefore, the primary focus of this analysis of risks and the development of risk management strategies is on these hitherto excluded target groups. In addition, smallholders generally constitute the vast majority of farmers in most countries. ${ }^{4}$

\section{Risks in Agricultural Finance}

\subsection{Definitions and Classifications of Risks}

\section{Risks in Agriculture Versus Risks in Agricultural Finance}

The high risks in agricultural finance are commonly quoted as the main constraint inhibiting financial institutions from lending to agriculture. Before engaging in more in-depth analysis, a distinction must be made between risks in agriculture and risks in agricultural finance. While the former is concerned with challenges and risks of agricultural production and marketing from the perspective of the farmer (real sector view), the latter reflects challenges and risks of lending to farmers from the viewpoint of a financial institution (financial sector view). Needless to say that both are interlinked, and real-sector risks of agricultural production determine to a large extent the financial-sector risks of agricultural lending. This chapter takes a financial sector perspective and is first of all concerned with the risk of agricultural finance where the specific risks of agricultural production form a sub-set of risks. The focus clearly is on credit risk although rural financial institutions also face other risks such as market, liquidity, and operational risks.

\section{Risks in Agriculture: Principal Risks Versus Specific Risks}

The risks that are relevant in agriculture have different characteristics, and they can be classified in very different ways. It is not necessary to opt for any particular classification of risk, and different ones can be used for different purposes. ${ }^{5}$ Following Baquet et al. (1997), for example, five major sources of risk in agriculture can be defined (OECD 2009):

3 Some even argue that agricultural SMEs and their unmet financial needs constitute the "missing middle of agricultural finance" (Doran et al., 2009).

4 In the Ukraine, for example, over six million small family farms account for 99 percent of all farmers and for 60 percent of agricultural output, while private commercial farmers comprise only 0.7 percent and large private agricultural enterprises only 0.3 percent in terms of numbers. (World Bank \& OECD 2004).

5 See OECD 2009 for an overview of different classifications of agricultural risk in recent literature. 
- Production risk concerns variations in crop yields and in livestock production due to weather conditions, diseases, and pests;

- Market risk is related to the variations in commodity prices and quantities that can be marketed;

- Financial risk relates to the ability to pay bills when due, to have money to continue farming, and to avoid bankruptcy;

- Legal and environmental risk concerns the possibility of lawsuits initiated by other businesses or individuals, and changes in government regulation related to environment;

- Human resources risk concerns the possibility that family or employees will not be available to provide labor or management to the farming business.

It is clear from the classification above that not all of the risks are specific to agriculture but that some are rather common to all businesses. This is true for most of the financial, legal, and human resources risks. Among the risks that affect agriculture more specifically are production risks (due to weather, pests, and diseases) as well as market and price risks. In recent years, climate change has appeared as a new phenomenon and risk category. Across the globe, it has a considerable influence on agricultural production and in some parts of the world has led to fundamental changes in production patterns and conditions. For the following discussion it is useful to differentiate between these principal (or common) risks and specific risks.

\section{Risks in Agricultural Finance}

Fundamentally, the risks in lending essentially hinge on the borrower's capacity and willingness to repay a loan, with the former depending on the viability of the business and the latter on the borrower's character. This is no different in agricultural lending. Here again, it is useful to differentiate between principal and specific risks. The risks in agricultural finance comprise to a considerable extent common risks associated with the viability of the farm business and the farmer's character, not much different from the risks of micro and small businesses in other economic sectors. In addition, farm businesses are exposed to specific production and market risks that may affect their repayment capacity. Finally, given the strategic importance of agriculture for food security, agricultural finance is subject to political interference in many countries. This poses significant political risks to agricultural lending institutions since political interventions often turn out to be detrimental to lending to farmers. Hence, the following sections discuss these three categories: principal credit risks, specific risks related to agriculture, and political risks.

\subsection{Principal Credit Risks}

Lending to small farmers exposes credit institutions to principal credit risks that are similar to those of micro and small enterprises in general. This is explained by 
similar patterns and characteristics of doing business. One characteristic is the high degree of informality as small farmers and enterprises are usually not registered. Household and enterprise activities are not separated. They are characterized by low levels of education and financial literacy. They rarely keep books of accounts and only few are able to produce financial statements. Most household enterprises do not have assets that could be pledged as collateral for loans from financial institutions.

For such businesses, credit institutions are exposed to significant information and monitoring problems. This is due to asymmetric information that exists when one party to a transaction (a lender) has less information than the other party (the borrower), and the resulting problems of moral hazard and adverse selection. Borrower screening and selection pose a tremendous challenge in such a situation. Finally, poor legal frameworks and systems create enormous enforcement problems. On top of all this, the poor state of the physical infrastructure (roads, electricity, telecommunication, etc.) in rural areas in many parts of the world further increases the risk and the cost for rural financial institutions.

Arguably, it is these principal credit risks that have prevented formal financial institutions from providing financial services and have resulted in financial exclusion of large parts of the society. This exclusion applies to micro and small enterprises and small farmers alike.

\subsection{Specific Risks in Agriculture}

Specific risks in agricultural finance mainly comprise production risk, on the one hand, and market and price risk, on the other hand. Financial institutions around the globe seem to be reluctant to finance agriculture particularly because of the perceived prevalence of these two types of risks.

\section{Production Risk}

Production risk in agriculture arises from the high variability of production outcomes. Unlike most other entrepreneurs, farmers cannot predict with certainty the amount of output their production process will yield, because of external factors such as weather, pests, diseases, and other natural calamities. Such events are higher for farmers engaged in monoculture of crops that are particularly sensitive to the correct use of high-quality inputs or the timing of harvesting.

Production risk in agriculture can also be traced to farmers seeking to increase their incomes through higher-risk, higher-return cropping strategies (Christen and Pearce 2005, p.2). The production of most high-yielding crops is relatively complex, involving careful timing of numerous steps - from preparing land through planting, fertilizing, and harvesting. Mistakes or delays at any step can substantially reduce returns - or eliminate them altogether. Moreover, climate change is regarded as steadily increasing the production risk (OECD, 2009). 


\section{Market and Price Risks}

Market risks are typically more pronounced in agriculture than in other economic sectors. Both input and output price volatility are sources of market risk in agriculture. Prices of agricultural commodities are typically volatile and farmers face a considerable price uncertainty. The price of the harvested output is typically not known at the time of planting when the production decisions are taken. Prices of agricultural commodities vary with levels of production and demand at the time of sale.

Moreover, farmers have no real way of knowing how many others are planting a specific crop or how average yields will fare in any given year. Often, a good price in one year motivates a lot of farmers to move into the same crop the next year. This shift increases production in the face of constant demand, driving down the price and making the crop much less attractive the following year. ${ }^{6}$ Christen and Pearce (2005) present the example of Uganda where a bumper maize harvest in 2001 and 2002 caused maize prices (and farmer incomes) to fall, significantly affecting loan repayment.

Segmented agricultural markets are influenced mainly by local supply and demand conditions, while more globally integrated markets are significantly affected by international production dynamics. In local markets, price risk is sometimes mitigated by the "natural hedge" effect, in which an increase (decrease) in annual production tends to decrease (increase) output price, while in integrated markets a reduction in prices is generally not correlated with local supply conditions, and therefore price shocks may affect producers in a more significant way (World Bank, 2005). However, even in local markets, distortions may prevent small farmers from benefitting from the "natural hedge." In many regions and for many crops there is a quasi-monopoly by certain local buyers. This may aggravate farmers' exposure to price and market risks. Furthermore, inelastic demand for many agricultural products is often cited as a main explanation for agricultural price variability where small increases in production can result in large price swings.

The extreme price swings in the global agricultural markets in the past three years has shown how market and price risks can be exacerbated by international market conditions. The hausse of the oil price from around US\$10 to over US\$150 per barrel in 2008 has dramatically changed the global commodity markets. Since then, crops and oil seeds are increasingly used for the production of ethanol and other biofuels in many parts of the (developed) world. The emergence of the biofuel industry has become a significant factor and price driver in international commodity exchanges. Global markets for staple crops such as wheat, corn, and soybeans have become the "battlefield of three giants," namely the food industry, the animal feed industry, and since recently the biofuel industry. The competition between these industries is likely to increase in the near to medium term and will significantly affect markets and prices across the globe (Rettburg, 2010).

6 This phenomenon was already described in 1928 by a German agronomist and became known as "pig cycle", see Hanau (1928). 
Finally, governments exert a significant influence on agricultural markets and prices in most countries. These and other interventions are dealt with under political risks in the subsequent section.

\section{Level and Correlation of Production and Market Risks}

Production and market risks exist at different levels and scale. Some risk events may occur at the micro level and affect a single farm household only, e.g. hail or fire, while others happen at the macro level and affect entire regions and countries like hurricanes or the recent widespread flooding in Pakistan. In between these two extremes, events of regional magnitude (meso level) may affect groups of farm households or communities in certain areas, e.g. floods or landslides.

Another important characteristic is that specific risks are often correlated. Corresponding to the levels described above, the correlation of risks can be located on a continuum from perfectly independent or idiosyncratic at the micro level to perfectly correlated or systemic at the macro level. In between these two poles, covariant risks are generally found at the meso level. Accounting for these correlations is crucial in developing efficient risk management strategies (OECD 2009). It is clear that correlated risks are difficult to pool compared to independent risks.

\subsection{Political Risks}

For governments in both developed and developing countries, agriculture is a strategic sector. Ensuring food security is high on the political agenda. In addition, agricultural commodities and products are a major export earner in many developing countries. Moreover, the agricultural sector often provides employment and income to a majority of the rural or total population and contributes significantly to GDP. This explains the highly political nature of agricultural sector in general and agricultural finance in particular, and the considerable degree of government interventions and interference in the sector.

Most countries have experienced politically motivated interventions and undue interference from government and politicians. Government interventions are directed either at the real sector, i.e. agricultural production and marketing, and/or at the financial sector, i.e. agricultural finance. Both types of interventions constitute a major political risk for financial institutions engaged in agricultural lending.

In many countries, the adequate and affordable supply of staple food crops to the growing urban population has been the primary rationale for interventions. Hence, price controls and subsidies with the focus on local urban consumers have been on the top of the menu of real sector interventions, often at the detriment of the rural population and the agricultural producers. In the past, many governments have directly engaged in the marketing of certain crops, primarily cash crops for export, by establishing state-run marketing boards and warehouses with direct price control. However many of these have disappeared in recent years. 
The creation or removal of tariff barriers can dramatically change local prices as the example of Ghana shows (Christen and Pearce, 2005). In the 1990s, the Ghanaian government introduced a limited exemption from import duties on white maize in response to a crop forecast - which later proved incorrect - that predicted a major food shortage. As a result, market prices for maize were depressed in Ghana for two years. Another most recent example of the effect of political intervention on crop prices has been the Russian prime minister Vladimir Putin's decision to ban Russian wheat exports following the drought and widespread fires last summer combined with irrational market psychology - has caused wheat prices to double in international markets from US\$4 to US\$8 per bushel within a few weeks.

The record of government interventions in the financial sector or agricultural finance is equally long (and discouraging). While most of the features from the era of supply-led agricultural finance with state-owned agricultural development banks and massive subsidized credit programs belong to the past, agricultural finance and the financial institutions engaged in the sector continue to be target of interventions. The imposition of lending quotas and interest rate ceilings are common features in many countries. Unrealistic limits on interest rates and interest margins discourage or inhibit financial institutions from engaging in rural and agricultural lending that involves high transaction costs. Even more serious are populist interventions such as farm debt relief and debt forgiveness programs. Such populist measures expose rural and agricultural lending institutions to considerable risk.

A striking example in this regard is Thailand where the populist Thaksin government announced a debt moratorium for small farmers in 2001 that seriously affected the Bank for Agriculture and Agricultural Cooperatives (BAAC). More than two million farmers owing over US\$1.7 billion-a third of BAAC's portfolio- enrolled in the program. As a result, BAAC's loan write-off rate jumped from three percent in 2001 to 12 percent in 2002, and its reserves for bad debt rose to 21 percent of its loan portfolio. (Christen and Pearce, 2005)

Another recent case occurred in India in February 2008 when the government announced a comprehensive loan waiver for small farmers, which has been primarily executed by the credit cooperatives. Preliminary data indicate that approximately 369,000 farmers have benefited from the debt forgiveness. One of the immediate impacts has been a steep drop in the recovery rates. Moreover, it has negatively affected the overall credit culture: a recent survey showed that one out of every four respondents want to wait for another loan waiver.

\subsection{Empirical Evidence on Actual Risks}

The literature reviewed, unfortunately, does not provide any empirical evidence on the types of risks that do actually cause losses for farmers and financial institutions. Specifically, no data have been found to confirm the argument that agricultural loans are more risky than others (Meyer, 2011). There are occasional in- 
stances and examples of floods or droughts in certain regions that have led to nonperforming loans or even defaults. ${ }^{7}$ However, other anecdotal evidence suggests that the main reasons for default of small farmers are like with any other micro or small business, e.g. the death of the owner, fire, or obvious cases of moral hazard and unwillingness to repay. In other words, it seems that in an overall perspective the principal risks matter more than the specific risks of agriculture.

\section{Approaches to Risk Management in Agricultural Finance}

Different types of risk call for different risk management approaches. This section sheds light on how principal, specific, and political risks in agricultural finance can be best managed.

\subsection{Managing Principal Credit Risks}

\section{Typical Risk Management Mechanisms and Their Limitations}

Rural and agricultural lending institutions have developed a number of mechanisms and techniques for managing the risks that arise from farmers' inability and/or unwillingness to repay their loans. For addressing the individual credit risk, there are two broad approaches: appraisal of repayment capacity and asset-backed lending. The former approach focuses on analyzing the debt capacity of a potential borrower using either human experts or statistical models, while the latter focuses on the quality and quantity of assets that can be pledged as collateral and how quickly that collateral can be liquidated in the event of a default (Wenner, 2010). Frequently, a combination of both approaches can be found.

\section{Asset-Backed Lending: Focus on Collateral}

Many financial institutions, especially commercial banks, pursue an asset-backed lending approach and require hard collateral as prime protection against default. In general, they require immovable assets - i.e. land - to be pledged as collateral, especially from farmers whose major - if not sole - productive asset is land. For this reason, land as collateral has an important psychological effect on borrowers' behavior because it functions as a powerful incentive device for maintaining the repayment morale.

However, the reality in most countries severely limits the collateral options. Firstly, formal collateral in the form of land titles is rarely available. In most

7 Examples are Morocco where the Gharb region was flooded for two consecutive years and the leading MFI Al Amana saw an increase of PAR in that region. Also in Mali in the Sikasso region, BNDA had high defaults from potato growers following floods in 2009. Source: personal communication with Christine Westercamp. 
cases, land is not formally registered, ownership is unclear, and property rights are insecure. Secondly, even when land titles are available, contract enforcement opportunities are poor. In rural communities it is very difficult if not impossible to liquidate and sell land as nobody would acquire land that belonged to a neighbor. This is currently experienced by Kreditimi rural I Kosoves (KrK), a rural MFI in Kosovo that has piled up land titles and even movable assets such as vehicles, which it finds almost impossible to sell in the rural community. ${ }^{8}$ Thirdly, small farmers are extremely reluctant to pledge land as collateral in fear of loss. A loss of land would wipe out the basis for existence. Fourthly, the formal registration of collateral titles can be very costly relative to the small loan sizes. As a result, the overemphasis on immovable collateral (land) has led to significant financial exclusion especially among small farmers.

Most lending institutions are reluctant to accept movable assets such as agricultural machinery, equipment, and vehicles as collateral due to the absence of secured transactions frameworks and collateral registries for movable assets in many countries. The same applies to alternative forms of collateral, e.g. livestock, standing crop (future harvest), or household equipment that farmers would be more easily prepared to pledge as collateral.

\section{Expert-Based Appraisal of Repayment Capacity}

Assessing repayment capacity requires a thorough understanding of the agricultural business, and of the risks and factors that determine success or failure. Agricultural lending requires specific technical expertise among loan officers and credit staff, capable of conducting the financial analysis of the borrower and structuring a loan that is tailored to the cash flow of the business. Agriculture requires a wide range of expertise, given the variety of crops and production methods; therefore, an expert-based evaluation system is expensive to both develop and maintain. In addition, technical expertise needs to match with adequate products and systems, for example with information technology (IT).

The inclusion of agricultural experts among credit staff has frequently led to an overly technical lending approach. The technical experts focused on agricultural "projects" as stand-alone activity, often isolated from the farm household economy, and developed differentiated loan products for different crops, i.e. "crop loans." Such "project finance" approach, however, is not appropriate for micro and small farmers; this has been a key lesson from successful microfinance institutions that apply a holistic approach to farm household enterprises.

In addition to these mechanisms with focus on individual credit risk, financial institutions have developed risk management tools at the portfolio level such as diversification, exposure limits, and loan loss reserves.

8 Author's personal insight as member of the Board of Directors of KrK. 


\section{Portfolio Management: Exposure Limits and Diversification}

Successful rural financial institutions engage in active portfolio management (1) by setting exposure limits for agricultural loans in the overall portfolio and (2) through diversification of their portfolios. For example, recent survey data in Latin America found that the average exposure to agriculture is less than 40 percent of the total portfolio (Wenner, 2010). Microfinance institutions tend to limit agricultural lending to less than one-third of their portfolios (Christen and Pearce 2005). Portfolio diversification is done in two ways. Firstly, diversification of the agricultural loans by geographic region, commodity, and type of farm household. However, due to covariant and systemic risks this technique can be implemented only by large institutions that operate in more than one agro-climatic zone. Secondly, diversification beyond agriculture to include off-farm and non-farm activities and enterprises.

\section{Building Risk Reserves: Loan Loss Provisioning}

Building risk reserves in the form of loan loss provisions, i.e. an internal absorption of credit risk, is the last line of defense for a financial institution. It is also the most costly measure as it negatively impacts profitability. This will of course depend on the prevailing regulations on loan classification and provisioning. Riskbased supervision norms that allow specific provisions are not yet prevalent in many developing countries.

The above mentioned typical risk management techniques are useful but they can only partially address the information, monitoring, incentive, and enforcement problems that prevent agricultural finance from reaching small and informal farmers in rural areas.

\section{Lessons Learned from Successful Agricultural Lenders}

While most of the state-owned agricultural development banks - agents of the "old paradigm" of agricultural finance - have failed, there are a few examples that have survived and been transformed into successful rural and agricultural lending institutions. The most notable cases are the Bank for Agriculture and Agricultural Cooperatives (BAAC) in Thailand and Bank Rakyat Indonesia (BRI). ${ }^{9}$ Both of these banks have developed systems and mechanisms that enabled them to manage the risks of lending to small farmers.

During the 1980s and 1990s, both banks made the decisive shift from agricultural credit to rural finance. This shift had two dimensions: (1) moving from credit-only institutions to full-service financial intermediaries with the introduction of savings facilities as an important financial service needed and demanded by farm households; and (2) a diversification from agricultural credit to rural credit for off- and non-farm activities and households. These two features have been essential for better managing the risks described above.

9 Literature on BRI: M. Robinson (2001), Maurer (2004) and on BAAC: Yaron (1992), Maurer (2000). 
In response to the collateral problem - many farmers did not have the legal documents showing proof of land ownership - BAAC developed a mechanism of joint liability groups, and this became an effective risk management device (risk pooling) and the trade-mark of BAAC's lending operations. Client farmers were asked to form small, informal groups of about 15 members that serve to guarantee the individual farmer's loans. However, BAAC does not extend group loans. All transactions are conducted with the individual members. The groups help BAAC in borrower screening, loan appraisal, and verification of data about loan applicants, as well as to maintain repayment discipline. In this way, BAAC reached more than 3.5 million small farmers organized in over 230,000 groups (Maurer, 2000).

The list of lessons to be learned from these two banks extends further. In fact, many rural and agricultural finance institutions from around the world have visited $\mathrm{BRI}$ and BAAC and have adopted successful elements in their own institutions.

\section{Contractual Arrangements and Agricultural Value Chains}

Interlinked contracts and agricultural value chains are features that have received increased attention. Interlinked transactions between farmers and buyers and intermediaries in agricultural value chains can significantly ameliorate asymmetric information and the problems of moral hazard and adverse selection, and hence reduce the risk for external lenders.

Financial services can be linked or embedded in value chains. Traders, processors, and other agribusinesses frequently supply internal finance along the chain by linking credit to the delivery of inputs or subsequent sale of produce. However, value chain finance has so far been mainly concentrated in higher-value export crops or commodities rather than in staple food production for local or regional markets. (Doran et al., 2009; Swinnen, 2011)

\section{Lessons Learned from Rural Microfinance}

Microfinance emerged in the late 1970s and 1980s and has since revolutionized traditional views by showing that the poor are bankable (Nagarajan and Meyer, 2005). Microfinance institutions (MFIs) developed a specific microcredit technology that has been highly effective in managing the principal risks of lending to small and informal household enterprises. This was further supported by an efficient organization, and standardized products and procedures that kept the cost of administering many small loans at reasonable levels.

Cash flow-based lending has proven a successful methodology for microenterprises that have little or no assets, while tiny and very small loans have been extended to very poor households for livelihood activities through a character-based lending methodology. In fact, many MFIs use a combination of both methodologies. A key factor is the holistic view of the household enterprise and the recognition that the line between "productive" and "consumptive" expenses is blurred. As a consequence, micro loans are for general purpose and not for a specific "project," which in any case is an alien concept to informal household enterprises. This 
takes into account the fact that most household enterprises - including small farm households - have multiple economic activities and income sources as part of their own risk management strategy, as shown in the next section.

Overall, microfinance has shown that it is possible to manage the principal risks that arise from the fundamental information, monitoring, incentive, and enforcement problems that exist in the rural and informal sector economies in developing countries. However, the other side of the coin is the high administrative cost of these successful risk management efforts in microfinance and the resulting, relatively high lending rates required to cover this cost. It is not clear whether all farming activities allow to pay such rates. Little analysis has been conducted in recent years on rates of return earned in farming relative to interest rates on loans. However, empirical studies of the productivity in agriculture and the use of inputs like fertilizer suggest the possibility of earning higher returns in agriculture (Meyer, 2011).

The other caveat is that standard microfinance technology offers only a partial solution for advancing agricultural finance. Most microfinance programs until now offer only short-term credit and require regular repayment in weekly or monthly installments that are most suitable for small traders and microenterprises in the service sector but are less appropriate for agricultural production and investment. Hence, adaptations and fine-tuning to the needs of small farmers will be required.

\section{Emergence of a New Paradigm in Rural Finance}

Based on the lessons learned from the old paradigm, from successful agricultural lenders, and from the microfinance revolution, a new rural finance paradigm emerged in the mid-1990s and is still being fine-tuned. This new paradigm reflects a financial systems approach, using market principles to deliver financial services aimed at rural development and poverty reduction (Nagarajan and Meyer, 2005). In terms of risk management, a model is emerging that combines the most relevant and promising features of conventional risk management, traditional agricultural finance, and microfinance. With this combination, rural financial institutions are able to successfully manage the risks of lending to rural microenterprises and households - including farm households - to a large extent. The challenge remains to adequately account for the specific risks in agriculture - as well as the political risks - and to integrate these in a comprehensive risk management approach.

\subsection{Approaches to Manage the Specific Risks in Agriculture}

Financial institutions are particularly reluctant to assume the specific risks in agriculture, i.e. the uncontrolled production and market risks, as these translate into credit risks that are more difficult to manage. As a consequence, banks seek to share or, more preferably, to transfer these risks to third parties. The following sections therefore look at potential risk sharing and risk transfer mechanisms from a conceptual angle. 


\section{Segmenting Risks into Layers}

A basic risk management technique consists of segmenting risk into different layers. This segmentation may help to match each set of risks with different "buyers" of risk or available risk management mechanisms (World Bank, 2005). These layers can be defined along a set of risk characteristics: (1) the level of risk (micro, meso, macro); (2) the degree of correlation (idiosyncratic, covariant, systemic); (3) the probability of occurrence (frequent, less frequent, seldom); and (4) the magnitude of the losses (low, medium, high) (see Appendix 1).

The first layer refers to losses that are part of the normal business environment for an individual farmer (micro level). They are very frequent but cause relatively limited losses, for example small weather shocks such as hail. Farmers should themselves assume and manage this type of risk with the instruments and strategies that are available at the farm, household or community level. This is "normal risk" or risk retention layer.

The second layer corresponds to risks at the meso level that are more significant and less frequent. However, both frequency and magnitude are in a middle range affecting groups of farmers or communities, for example a severe weather shock leading to floods. In this layer there is scope for farmers to use specific market instruments such as insurance or options that are particularly designed to deal with farming risk, as far as these are available. This is the market solutions (insurance) layer.

The third layer comprises risks that are catastrophic in nature because they generate very large losses, even if their frequency is low, for example hurricanes or widespread drought. This type of risk is more difficult to share or pool through the market mechanism, particularly if it is systemic. For example, the loss and damage caused by the Tsunami in Indonesia led to insolvency of one of the largest insurance company in Indonesia. There is a role for government, with the assistance of the international donor community, in the case of catastrophic risk. This is the market failure layer.

\section{Risk Retention by Farmers: Prevention, Mitigation and Coping Strategies}

Farmers typically manage the "normal" risk of the first layer with "self-protection" or "self-insurance" strategies or activities. It is common to differentiate farmers" strategies into three main categories: (1) prevention strategies to reduce the probability of an adverse event occurring; (2) mitigation strategies to reduce the potential impact of an adverse event; and (3) coping strategies to relieve the impact of the risky event once it has occurred (OECD, 2009). Risk prevention and mitigation strategies attempt to address risk ex ante; risk coping strategies address risk ex post. Mahul and Stutley (2010) differentiate between technical and financial strategies. Technical strategies include, for example, the application of pesticides, vaccination to prevent livestock disease, or crop rotation. Financial strategies comprise precautionary savings, contingent borrowing, or purchase of crop insurance, if available. 
Strategies can be based on informal and formal mechanisms. Risk management by farmers is conducted mostly through informal mechanisms, especially among small and marginal farmers who have limited access to formal mechanisms and market instruments such as insurance or hedging.

Over centuries, farmers have developed a myriad of traditional risk management strategies in their respective socio-cultural environments. For example, farmers have developed preservation methods and created storage facilities, household or community-based, in order to cope with price fluctuations and to manage price risks. Farmers in many regions engage in risk sharing arrangements through sharecropping. Contractual arrangements such as forward sale of standing crop are common mechanisms for farmers to reduce price risk.

Traditional forms of precautionary savings are found in almost every agricultural society as a coping strategy, e.g. the handful of rice that is taken aside in a clay pot before preparing the daily meal. Other traditional forms of saving include cattle and other animals, building materials, fire wood, etc. The more important it is that rural financial institutions offer savings facilities, a financial service which was absent in the old paradigm era of agricultural credit. ${ }^{10}$

The risk awareness among farmers is generally high and the significant exposure to production and market risks explains farmers' risk aversion to new technologies, methods, or crops. Risk diversification is an important element in farmers' self-protection strategies. This includes on-farm diversification such as intercropping and crop rotation but also the diversification of income sources to include off-farm and non-farm activities. Survey data from the Consultative Group to Assist the Poor (2005) show that the average share of non-farm household income is considerable: it is highest in Africa (42 percent) and Latin America (40 percent), but also significant in Asia (32 percent). Through multiple incomegenerating activities small farmers are generally better protected to specific risks in agriculture than highly specialized commercial farmers, especially those engaged in monoculture and single crop cultivation.

The menu of tools and strategies that are available can be different in different countries and for different farmers, for instance due to their size, location, or availability of information, some farmers may have more difficult access to market instruments than other farmers. The farmer chooses among available instruments the combination of tools and strategies that best fits his risk exposure and his level of risk aversion (OECD, 2009) at reasonable cost.

\section{Risk Pooling and Risk Transfer: Market Solutions and Instruments}

Risk pooling and risk transfer present solutions to deal with second-layer risks that are more significant and less frequent, and where both frequency and magnitude are in a middle range. In this layer there is scope for farmers to use additional specific market instruments, such as insurance or options that are particularly designed to deal with farming risk.

10 Vogel (1984) illustratively termed savings as the forgotten half of rural finance. 


\section{Traditional Crop Insurance}

Agricultural insurance has existed for many years. According to a recent World Bank survey (Mahul and Stutley, 2010), ${ }^{11} 104$ countries - or more than half of all countries worldwide - offered some form of agricultural insurance in 2008. Global agricultural premium volume increased dramatically between 2004 and 2007, rising from US $\$ 8$ billion to about US $\$ 20$ billion. This stunning increase was caused by (1) rising agricultural commodity prices and total insured values; (2) expansion of agricultural insurance in China, Brazil, and Eastern Europe; and (3) increasing government subsidy support in major countries. However, agricultural insurance provision is dominated by high-income countries and China. ${ }^{12}$ Almost 90 percent of global agricultural insurance premium volume is underwritten in high-income countries.

Crop insurance has been the main product, accounting for an estimated 91 percent by premium volume, while livestock insurance makes up for much of the balance. There have been two traditional lines of crop insurance: multiple peril crop insurance (MPCI) programs and single-peril crop insurance. Most of the MCPI programs depend crucially on government support and subsidies. These programs, which have mostly been implemented in high-income countries, require levels of government support unfeasible for most developing countries (World Bank, 2005). Historically, the traditional crop insurance programs have performed very poorly. Since the 1990s, most developing countries witnessed a shift from public to market-based agricultural insurance and governments have promoted agricultural insurance through the commercial insurance sector, often under publicprivate partnerships. So far, however, unsubsidized private insurance has mostly been limited to single-peril insurance, e.g. hail insurance (OECD, 2009).

The main difficulty is argued to be the high transaction costs associated with crop insurance markets due to information asymmetries, and the resulting problems of moral hazard and adverse selection. Furthermore, the cost of distribution and administration of insurance services is significant for small-scale contracts with farmers in remote villages. This makes it nearly impossible to provide traditional agricultural insurance for small farmers (World Bank 2005). Premiums that are too expensive reduce or eliminate the demand from farmers at those prices. The demand for insurance is also affected by the relative costs of alternative strategies such as diversification and financial management (OECD, 2009). As an outcome, small and marginal farmers have generally been excluded from the traditional agricultural insurance programs, or insurance programs have never been effective and cost-efficient enough to compete successfully with coping mechanisms employed by the farmer himself.

11 The survey covered agricultural insurance programs in 65 countries, covering 52 percent of high-income countries, 69 percent of middle-income countries, and 50 percent of low-income countries that are known to offer some form of agricultural insurance.

12 In 2008 the agricultural insurance premium volume in China was estimated at $\$ 1.75$ billion, making it the second largest agricultural insurance market after the United States. (Mahul and Stutley, 2010). 


\section{Index-Based Insurance}

In recent years, index-based insurance schemes have emerged as an innovative and cost-efficient risk management tool that nurtures the hope of policymakers, donors, and development organizations that marginal and small farmers in developing countries can be provided with better support in managing their exposure to agricultural perils. In such insurance, indemnity payments are based on an index such as cumulative rainfall or aggregate crop yields in a geographical area, and not on the individual farmer's loss incurred.

Unlike in traditional crop insurance products, asymmetric information problems play a much smaller role in index-based insurance schemes. Firstly, a farmer mostly has little more information than the insurer regarding the index value, and secondly the index value cannot be influenced by individual farmers. Finally, administration costs are much lower as it does not require verification of individual loss claims, making it more affordable particularly for small and marginal farmers.

The development of index-based insurance is still at an early stage. Many index initiatives in developing countries have been supported by the donor community and the international reinsurance market. Most of the weather-based crop insurance programs are still under pilot implementation, with only few farmers insured so far. Hence, it is too early to judge their success, except in India where 400,000 farmers purchased weather-based crop insurance in 2008 (Mahul and Stutley, 2010). At present, the pilots face a number of technical and other obstacles such as the lack of high-quality weather data, inadequate distribution of weather stations, limited supply of people with risk-modeling capabilities and expertise in agricultural risk management, and weaknesses in regulatory and legal infrastructure. These problems hamper the pace of progress. ${ }^{13}$ Another obstacle for the mechanism is climate change. This is imposing a long-term trend of increasing risk, making the insurance approach more difficult to apply and more expensive (Doran et al., 2009).

A major disadvantage of index-based insurance is the so-called basis risk, i.e. the risk that payouts (triggered by an index) may not correspond with the losses a farmer actually incurs. The basis risk may be substantial, making it difficult for farmers to understand and accept (Skees, 2008). In addition, (re)insurance companies are reluctant to take the reputation risk associated with possible negative media coverage if poor farmers in developing countries are not indemnified for their losses although they bought insurance cover (Levin and Reinhard, 2007). Hence, the central challenge of index-based insurance products is to overcome the problems linked to the basis risk.

\section{Catastrophic Risk and Market Failure: Risk Transfer to Government}

Catastrophic events like natural disasters and extreme weather events generate very large and highly correlated losses, even if their frequency is low. This type of

13 For a more detailed overview of advantages and disadvantages of weather insurance see World Bank 2005, Table 4.1, p.18. 
risk is more difficult to pool and transfer through the market mechanism, particularly if it is systemic, affecting entire regions or even countries. Market failure will be the rule. Moreover, climate change has a significant impact on the frequency of catastrophic events worldwide. The data from the United Nations International Strategy for Disaster Reduction show a dramatic increase in the occurrence of natural disasters, particularly of hydro-meteorological events during the last century (OECD, 2009).

It is clear that not all agricultural risks are insurable: ${ }^{14}$ insurance contracts for some risks do not exist because the insurance premium covering all the costs would be prohibitive (OECD, 2009). Miranda and Glauber (1997) emphasize the need for risk to be independent among the insured, arguing that due to correlations among individual yields, crop insurers face portfolio risk that is about ten times larger than that faced by private insurers offering more conventional lines of insurance (automobile, fire, etc). And also reinsurers are reluctant to take portfolios with a probability of very large obligations. Natural disasters like the Tsunami in Southeast Asia in 2006, the earthquake in Haiti in 2008, and the recent countrywide flooding in Pakistan in 2010 are examples of catastrophic risk where market instruments break down and which call for the government, supported by the international donor community, to step in with emergency aid, disaster relief, and safety net provision.

Synthesis: Structured Risk Management
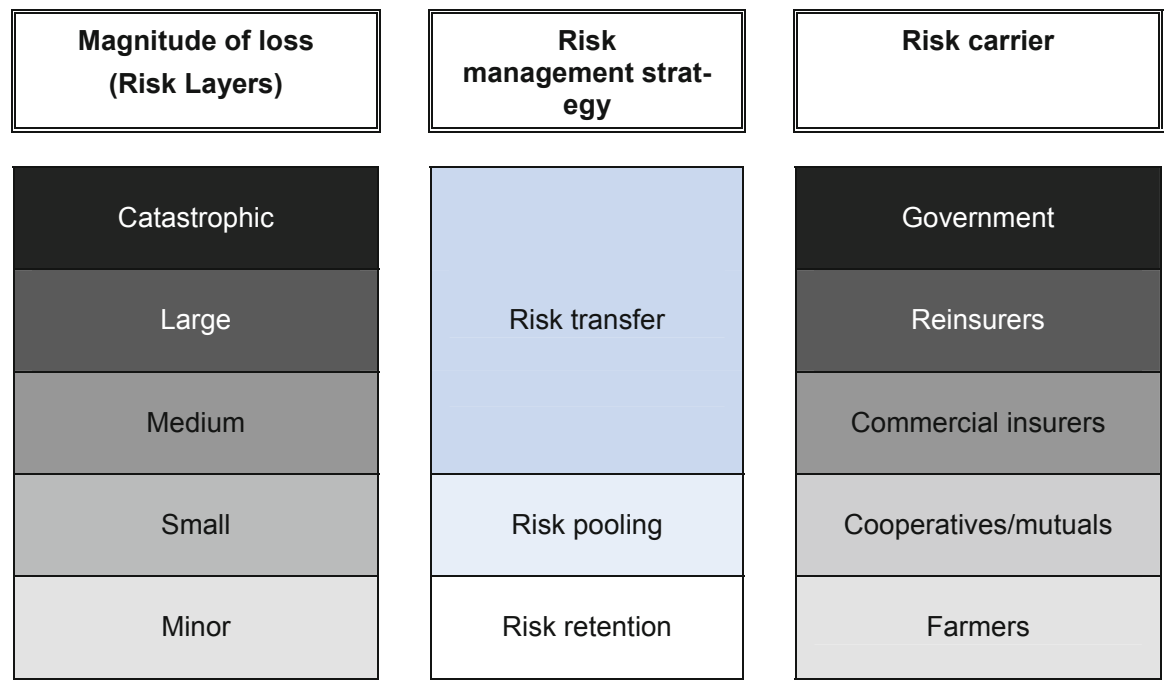

Fig. 1. Structured Risk Management

Source: Own illustration based on Mahul and Stutley (2010)

14 OECD (2009) lists a number of conditions for the insurability of agricultural risks. 
Figure 1 above summarizes the preceding sections in a structured risk management model that integrates the different risk layers and allocates risk-taking functions according to magnitude of losses.

The model above contains two intermediate layers at both the low and high end. At the low end, it introduces risk pooling by cooperatives and mutuals as risk carriers for small losses. This mechanism can, for example, effectively mitigate or even eliminate the basis risk in index-based insurance schemes. At the high end, re-insurance can play an important role in pushing the frontier of commercial insurance toward large and partially systemic risks, thereby increasing the scope of market solutions and confining the role of government to truly catastrophic risk.

\section{Relevance for Financial Institutions}

The concept of risk pooling and transfer through insurance is appealing in theory, but reality and thus the benefit for banks is a different story. Traditional crop insurance exists in many countries but it requires large amounts of subsidies and the vast majority of small farmers have no access to it. The promise of index-based insurance is large and expectations are high, but its implementation is still in a pilot stage and its up-scaling potential and sustainability remain untested. Furthermore, climate change is steadily increasing risk, reducing the scope of the insurance approach.

Credit guarantee funds have been promoted to fill this void, often along with technical assistance and training. For example, USAID has been promoting partial guarantee programs through its Development Credit Authority (DCA) in several countries. Skepticism about the impact, additionality, and sustainability of credit guarantee funds go hand-in-hand with (renewed) enthusiasm. There is a new generation of guarantors - e.g. powerful philanthropic foundations, IFIs, etc. - whose contracts with banks have features that could produce outcomes better than those of historic government guarantee funds (Doran et al., 2009). Overall, however, the case for credit guarantees continues to be unclear, as summarized by Meyer (2011): "It is possible that guarantees may provide an additional bit of comfort for financial institutions that are interested in testing the feasibility of lending to a new clientele group. However, it is unlikely that a guarantee alone will induce much additional lending by lenders who do not have such an interest."

Hence, until market-based risk transfer mechanisms become broadly available, financial institutions will have to rely on their conventional risk management techniques such as portfolio diversification and exposure limits. In addition, risk retention by farmers themselves will be a first line of defense. Farmers' prevention, mitigation, and coping strategies are crucially important and banks need to learn more about these "self-protection" tools and take these into account in their overall risk assessment. In addition, risk pooling through groups and cooperatives can be an important complementary feature as the experience of successful agricultural lenders, such as BAAC, shows. 


\subsection{Political Risks Remain a Challenge}

The political risk of government intervention and interference in agricultural finance, whether persistent or unpredictable, is perhaps the risk most difficult to control and to manage by agricultural lenders. In most cases, little can be done to prevent interference or mitigate its negative effect.

BAAC in Thailand, for example, during the 1990s adopted a strategy of "interventions against compensations" through intensive lobbying and policy dialogue with the government officials and members of parliament in order to mitigate or neutralize the intervention effects on the bank's financial viability. On the one hand, these efforts were partially successful but, on the other, they invited even harsher interventions as BAAC's bargaining power diminished. In 1995 the bank was forced to reduce its lending rate for small loans under US\$2,400 to lossmaking levels, affecting more than a third of its loan portfolio (Maurer, 2000), and in 2001 the government imposed an extensive debt moratorium on farm loans (see above).

The source of funding of agricultural credit can have an influence on government. The case of Bank Rakyat Indonesia in Indonesia has shown that if agricultural lenders are mainly financed by local savings deposits instead of refinance lines from the government, and if they are under prudential regulation and supervision of the central bank they might be subject to interference from government and politicians to a lesser extent.

Amid the recent rise in commodity prices and increasing concerns about food security, government intervention in agricultural markets and agricultural finance will likely remain a considerable - and perhaps even the greatest - source of risk for agricultural lenders.

\section{Implications and Perspectives for Agricultural Finance}

\subsection{Towards a Hybrid Model of Agricultural Microfinance}

A hybrid model - or rather models - of agricultural microfinance has been emerging that combines and incorporates lessons learned from traditional agricultural finance, especially from successful agricultural lending institutions, from microfinance, from the financial systems approach in general, and from recent experience with innovative insurance instruments. Christen and Pearce (2005) have presented ten key features of such a hybrid model (see Appendix 1), much in line with the new paradigm of rural finance.

Some of these features are directly related to credit risk and risk management, for example, the principle that repayments are not linked to loan use (feature 1) and the character-based lending technology combined with technical analysis (feature 2). The model suggests to provide savings services (feature 3) that enables precautionary savings as an important coping mechanism for farmers. Portfolio 
diversification is a key element (feature 4) and when loan terms and conditions are adjusted to accommodate cyclical cash flows (feature 5) the risk of non-repayment is lowered considerably.

Such hybrid models will expand the frontier of outreach specifically to small farmers in distant rural areas, and will help to manage and mitigate much of the principal and some of the specific credit risks. As such, the models cater to the vast majority of farmers in most countries but they are less applicable to large farms and agricultural enterprises. Moreover, as the models seek to incorporate innovative market instruments such as index-based microinsurance (feature 9) though still being under development - or contractual arrangements to reduce price risk (feature 6) they offer the potential of controlling and managing also the specific risks of agricultural finance, at least to the extent that such risks are insurable. Certainly, managing catastrophic risk (market failure layer) will remain outside of the scope of such model.

Furthermore, these models serve to reduce the cost of rural and agricultural lending. For example, recently developed models of mobile and branchless banking may provide cost-efficient solutions to reach out to farmers in remote rural areas (feature 7).

\subsection{Innovative Insurance Instruments Need Further Study and Development}

While initial experience with index-based insurance pilot projects seems to be very promising, further research and monitoring of these initiatives needs to be done to enable conclusions to be drawn about their sustainability, financial viability, and implementation on a larger scale. At the same time, advances in technology, e.g. the use of satellite images, will lead to a better availability of data needed to properly calculate and offer index-based insurance policies (Levin and Reinhard, 2007). While the first pilot projects focus purely on the protection of small farmers affected by negative weather events, index-based insurance products are also attractive to agribusiness intermediaries along the value chain, such as input suppliers, processors and traders whose business operations are correlated with agricultural products. A collaboration with (re-)insurance companies can foster the development of yield-insurance products that are inexpensive, sustainable, and appropriately designed.

\subsection{Diversification to Remain a Core Element of Risk Management}

Diversification is and will remain one of the primary risk mitigation strategies used by microfinance institutions and rural banks engaged in agricultural lending. For financial institutions, agricultural lending cannot be the primary type of lending unless robust risk transfer techniques become more commonplace, especially for small and marginal farmers. Financial institutions must counter unrealistic ex- 
pectations and withstand political pressure to engage non-prudently and excessively in agricultural lending. Under a prudent financial sector approach finance follows the real sector. Hence, the share of value added in agriculture as percent of GDP may serve as a benchmark for financial institutions' exposure to agriculture. According to the World Bank, in 2008 the average share of agriculture was 7 percent in Latin America, about 12 percent in most of East Asia and Sub-Sahara Africa, and 18 percent in South Asia. Hence, setting a ceiling on the share of agricultural loans between 10 percent and 30 percent of a loan portfolio, depending on the region, seems plausible and prudent.

In addition, diversified portfolios of the financial institutions must be complemented by risk diversification by the farmers themselves. Only a small share of the smallholders will grow and emerge as specialized commercial farmers, but the large majority of small farmers will likely remain family or household enterprises. For these, risk mitigation through diversification of income sources will remain a key risk management strategy. Successful agricultural lenders will look more closely at the risk retention layer and analyze the farmer's own risk management capacity in terms of prevention, mitigation, and coping strategies as a factor of creditworthiness. Precautionary savings play a crucial role and thus it is essential that safe, convenient, and accessible savings facilities are offered by financial institutions.

\subsection{Improvements in Legal Framework and Financial Infrastructure}

In most countries, improvements in the legal and regulatory frameworks are necessary as they pertain to agriculture and agricultural finance. This encompasses systems of clear property rights and especially improved cadastre systems related to land ownership and registry. Another key element is a strong legal framework for secured transactions. Such framework should particularly include a collateral registry for movable assets that would allow farmers to pledge equipment and machinery as collateral as well as facilitate leasing of agricultural equipment. Expanding the collateral options would greatly improve farmers' access to credit, on the one hand, and financial institutions' risk management, on the other hand.

\subsection{The Role of Government and Donors}

The first and foremost role of government is to refrain from undue interference in agricultural finance by adopting a "do no harm" principle. Admittedly, this is easier said than done. However, politically motivated loan waivers, and other such drastic and damaging interventions, have no place in an environment of responsible finance. Governments around the world should finally move away from the old paradigm of directed lending, interest rate controls, and massive subsidies, and should adopt lessons learned and support good practices that have emerged under the new paradigm of rural and microfinance. 
A positive role for the government is seen in creating an enabling environment and legal framework as outlined in the previous section, developing the risk market infrastructure, enforcement of regulations, and a supportive rural infrastructure. This would eventually lead to lower but sustainable interest rates by reducing risks and transaction costs and increasing competition. The primary role of government should be to address market and regulatory imperfections in order to encourage participation by the private sector in providing not only agricultural credit but the whole range of financial services including savings facilities and insurance.

As insurance instruments and other risk transfer mechanisms are being developed and tested, some public support and limited subsidies may be required. However, in the medium to long term the government's role should be confined to catastrophic risk as a result of severe events like natural disasters. This is when the market fails and the government is needed in a last resort function of disaster relief and social safety net provision.

Donors and development finance institutions (DFIs) have an important advocacy role by engaging in a dialogue with governments on conducive policies and frameworks for agricultural finance and by facilitating exchange and learning on lessons and good practices. Donor support is most valuable in venturing and pilottesting innovative approaches to risk management. The World Bank's lead initiative in developing and promoting index-based insurance in numerous pilot projects is an example in this regard. Furthermore, donors and DFIs can facilitate and catalyze public-private partnerships (PPP), especially for developing mechanisms of risk transfer to the international and global markets. Finally, dealing with catastrophic events like the Tsunami in Southeast Asia or the 2010 country-wide flooding in Pakistan is beyond the scope of national governments and thus require concerted relief efforts of the international donor community.

\section{$5 \quad$ Concluding Remarks}

The risk of lending to small famers is not as high, let alone "prohibitive," as frequently claimed by financial institutions. A large - if not overwhelming - part of the risk can be regarded as principal or normal credit risk, which does not much differ from lending to microenterprises in general. These risks can be fairly well managed by applying features of the hybrid model of agricultural microfinance presented above.

More difficult to deal with are the specific risks of agriculture. Crop insurance - publicly provided and highly subsidized - is available in many countries but is not accessible by the vast majority of small farmers. While the concept of risk transfer is appealing and would undoubtedly present a first-best solution, the implementation of market-based insurance schemes is still in a pilot stage.

Until such market-based insurance products become broadly available, agricultural finance will have to rely on second-best solutions. These comprise conventional risk management techniques such as portfolio diversification on the side of 
the lenders combined with risk prevention, mitigation, and coping strategies on the side of the borrowers.

Finally, it should be emphasized that agricultural finance comprises - or should comprise - more than just credit. Farm households need money transfer and payment services and, most importantly, savings facilities. Savings have been, and will continue to be, a key feature of successful agricultural finance institutions.

\section{Appendix 1: Segmentation of Agricultural Risks}

\begin{tabular}{|c|c|c|c|}
\hline Level of risk & Micro & Meso & Macro \\
\hline Affected groups & $\begin{array}{l}\text { Individual farm } \\
\text { household }\end{array}$ & $\begin{array}{l}\text { Groups of } \\
\text { households or } \\
\text { communities }\end{array}$ & Regions or entire country \\
\hline $\begin{array}{l}\text { Degree of } \\
\text { correlation }\end{array}$ & $\begin{array}{l}\text { Idiosyncratic risk } \\
\text { (independent) }\end{array}$ & Covariant risk & $\begin{array}{l}\text { Systemic or catastrophic } \\
\text { risk }\end{array}$ \\
\hline $\begin{array}{l}\text { Probability of } \\
\text { occurrence }\end{array}$ & Very frequent & Less frequent & Low frequency \\
\hline $\begin{array}{l}\text { Magnitude of } \\
\text { losses }\end{array}$ & Small losses & Significant losses & Very large losses \\
\hline $\begin{array}{l}\text { Incidence and } \\
\text { Examples }\end{array}$ & $\begin{array}{l}\text { Regular variation in } \\
\text { production: } \\
\text { - smaller weather } \\
\text { shocks, e.g. hail, } \\
\text { frost } \\
\text { - non-contagious } \\
\text { diseases } \\
\text { - Independent } \\
\text { events, e.g. fire }\end{array}$ & $\begin{array}{l}\text { Large negative } \\
\text { production } \\
\text { shocks: } \\
\text { - severe weather } \\
\text { conditions, e.g. } \\
\text { flood } \\
\text { - pest infestation }\end{array}$ & $\begin{array}{l}\text { Highly systemic, shocks } \\
\text { affecting a large region and } \\
\text { leading to catastrophic } \\
\text { losses in production: } \\
\text { - hurricanes, widespread } \\
\text { flooding, drought } \\
\text { - epidemic diseases }\end{array}$ \\
\hline Risk Layer & Risk retention & $\begin{array}{l}\text { Market solutions } \\
\text { (Insurance) }\end{array}$ & Market failure \\
\hline Risk carrier & Farmers & $\begin{array}{l}\text { Private (re-)insur- } \\
\text { ance companies }\end{array}$ & Government/donors \\
\hline $\begin{array}{l}\text { Risk } \\
\text { management } \\
\text { strategy }\end{array}$ & $\begin{array}{l}\text { Risk reduction and } \\
\text { coping }\end{array}$ & $\begin{array}{l}\text { Risk pooling } \\
\text { (insurance) and } \\
\text { risk transfer }\end{array}$ & Risk transfer \\
\hline
\end{tabular}

Source: Own compilation based on World Bank, 2005; Levin and Reinhard, 2007; OECD 2009 


\section{Appendix 2: Features of a Hybrid Model of Agricultural Microfinance}

Feature 1: Repayments are not linked to loan use. Lenders assess borrower repayment capacity by looking at all of a household's income sources, not just the income (e.g. crop sales) produced by the investment of the loan proceeds. Borrowers understand that they are obliged to repay whether or not their particular use of the loan is successful. By treating farming households as complex financial units, with a number of income- generating activities and financial strategies for coping with their numerous obligations, agricultural microfinance programs have been able to dramatically increase repayment rates.

Feature 2: Character-based lending techniques are combined with technical criteria in selecting borrowers, setting loan terms, and enforcing repayment. To decrease credit risk, successful agricultural microlenders have developed lending models that combine reliance on character-based mechanisms - such as group guarantees or close follow-up on late payments - with knowledge of crop production techniques and markets for farm goods.

Feature 3: Savings mechanisms are provided. When rural financial institutions have offered deposit accounts to farming households, which helps them to save funds for lean times before harvests, the number of such accounts has quickly exceeded the number of loans.

Feature 4: Portfolio risk is highly diversified. Microfinance institutions that have successfully expanded into agricultural lending have tended to lend to a wide variety of farming households, including clients engaged in more than one crop or livestock activity. In doing so, they have ensured that their loan portfolios and the portfolios of their clients are better protected against agricultural and natural risks beyond their control.

Feature 5: Loan terms and conditions are adjusted to accommodate cyclical cash flows and bulky investments. Cash flows are highly cyclical in farming communities. Successful agricultural microlenders have modified loan terms and conditions to track these cash-flow cycles more closely without abandoning the essential principle that repayment is expected, regardless of the success or failure an any individual productive activity - even that for which the loan was used.

Feature 6: Contractual arrangements reduce price risk, enhance production quality, and help guarantee repayment. When the final quality or quantity of a particular crop is a core concern - for example, for agricultural traders and processors - contractual arrangements that combine technical assistance and provision of specified inputs on credit have worked to the advantage of both the farmer and the market intermediary. 
Feature 7: Financial service delivery piggy-backs on existing institutional infrastructure or is extended using technology. Attaching delivery of financial services to infrastructure already in place in rural areas, often for nonfinancial purposes, reduces transaction costs for lenders and borrowers alike, and creates potential for sustainable rural finance even in remote communities. Various technologies show enormous promise for lowering the costs of financial services in rural areas, including automated teller machines (ATMs), pointof-sale (POS) devices linked to "smart cards", and loan officers using personal digital assistants.

Feature 8: Membership-based organizations can facilitate rural access to financial services and be viable in remote areas. Lenders generally face much lower transaction costs when dealing with an association of farmers as opposed to numerous individual, dispersed farmers - if the association can administer loans effectively. Membership-based organizations can also be viable financial service providers themselves.

Feature 9: Area-based index insurance can protect against the risks of agricultural lending. Although government-sponsored agricultural insurance schemes have a poor record, area-based index insurance holds more promise for protecting lenders against the risks involved in agricultural lending.

Feature 10: To succeed, agricultural microfinance must be insulated from political interference. Agricultural microfinance cannot survive in the long term unless it is protected from political interference. Even the best-designed and bestexecuted programs wither in the face of government moratoriums on loan repayment or other such meddling in well-functioning systems of rural finance.

Source: Christen and Pearce, CGAP 2005

\section{References}

Baquet, A., Hambleton, R., Jose, D. (1997) Introduction to Risk Management. USDA Risk Management Agency.

Christen, R.P., Pearce, D. (2005) Managing risks and designing products for agricultural microfinance: Features of an emerging model. CGAP Occasional Paper No. 11.

Doran, A., McFayden, N., Vogel, R.C. (2009) The Missing Middle in Agricultural Finance. Relieving the capital constraints on smallholder groups and other agricultural SMEs. OXFAM Research Report.

Hanau, A. (1928) Die Prognose der Schweinepreise. Vierteljahreshefte zur Konjunkturforschung. Berlin. http://www.diw.de/documents/dokumentenarchiv/17/ 43353/viertel_1928.pdf. 
Höllinger, F., Rutten, L., Kiriakov, K. (2009) The use of Warehouse receipt finance in agriculture in transition countries. FAO Investment Centre.

Kloeppinger-Todd, R., Sharma, M. (eds.) (2010): Innovations in Rural and Agricultural Finance. International Food Policy Research Institute (IFPRI) and The World Bank.

Levin, T., Reinhard, D. (2007) Microinsurance aspects in agriculture. Discussion Paper. Munich Re Foundation.

Mahul, O., Stutley, C.J. (2010) Government Support to Agricultural Insurance Challenges and Options for Developing Countries. Washington DC: World Bank.

Meyer, R.L. (2011) A Review of Subsidies and Investments to Support Agricultural Credit Markets in Developing Countries. http://siteresources. worldbank.org/INTARD/Resources/Subsidies_as_Intrument_AgFin.pdf.

Maurer, K. (2000) Agricultural Development Bank Reform: The Case of the Bank for Agriculture and Agricultural Cooperatives (BAAC) in Thailand. IFAD.

Maurer, K. (2004) Bank Rakyat Indonesia. Twenty Years of Large-Scale Microfinance. In: Scaling up Poverty Reduction: Case Studies in Microfinance. CGAP $\&$ The World Bank.

Miranda, M.J., Glauber, J.W. (1997) Systemic Risk, Reinsurance, and Failure of Crop Insurance Markets. American Journal of Agricultural Economics 79:206215.

Nagarajan, G., Meyer, R.L. (2005) Rural Finance: Recent Advances and Emerging Lessons, Debates and Opportunities. Reformatted version of Working Paper No.(AEDE-WP-0041-05). Department of Agricultural, Environmental and Development Economics. Columbus, Ohio: The Ohio State University.

OECD (2009) Risk Management in Agriculture - A Holistic Conceptual Framework. Working Party on Agricultural Policies and Markets.

Rettburg, U. (2010) Wenn das Wetter die Preise bestimmt. Handelsblatt 24/25.

Robinson, M.S. (2001) The Microfinance Revolution. Sustainable Finance for the Poor. Washington DC and New York: The World Bank and Open Society Institute.

Skees, J.R. (2008) Innovations in Index Insurance for the Poor in Lower Income Countries. Agricultural and Resource Economics Review 37(1):1-15.

Swinnen, J.F.M., Maertens, M. (2013): Finance Through Food and Commodity Value Chains in a Globalized Economy. In this volume.

Vogel, R.C. (1984) Savings Mobilization - the forgotten half of rural finance. Economic Development Institute of the World Bank

Wenner, M.D. (2010): Credit Risk Management in Financing Agriculture. In: Kloeppinger-Todd/Sharma (2010). 
Wiedmaier-Pfister, M., Klein, B. (2010) Microinsurance Innovations in Rural Finance. In: Kloeppinger-Todd/Sharma (2010).

World Bank \& OECD (2004) Achieving Ukraine's Agricultural Potential. Stimulating agricultural growth and improving rural life. Joint publication. Washington DC.

World Bank (2005) Managing Agricultural Production Risk. Innovations in Developing Countries. Washington DC.

Yaron, J. (1992) Successful Rural Financial Institutions. World Bank Discussion Paper No.150. Washington DC: The World Bank. 